\title{
Quality Assessment of Mince Based Products Made from Mrigal (Cirrhinus mrigala) During Frozen Storage
}

\author{
T. Sandhya Rani ${ }^{1}$, K. Dhanapal ${ }^{1 *}$, G.V.S. Reddy ${ }^{2}$, D.R.K. $\operatorname{Reddy}^{3}$, \\ K. Sravani ${ }^{1}$ and G. Praveen Kumar ${ }^{1}$ \\ ${ }^{1}$ Department of Fish Processing Technology, College of Fishery Science, Sri Venkateswara \\ Veterinary University, Muthukur - 524 344, Andhra Pradesh, India \\ ${ }^{2}$ Fisheries Research Station, Palair, Khammam District, Telangana, India \\ ${ }^{3}$ Department of Aquaculture, College of Fishery Science, Sri Venkateswara Veterinary \\ University, Muthukur - 524 344, Andhra Pradesh, India \\ *Corresponding author
}

A B S T R A C T

\begin{tabular}{|l|}
\hline Key w or d s \\
Mrigal, Mince, \\
quality, \\
biochemical, \\
microbial, Shelf \\
life.
\end{tabular}

Cirrhinus mrigala is one of the most important fresh water fish cultured throughout the state of Andhra Pradesh. The fish is highly preferred in the market because of the taste and texture of the meat. However, one of the key factors limiting the use of this species is the presence of pin bones. Microbiological, chemical, proximate and sensory changes of value added mince based products prepared from mrigal (Cirrhinus mrigala) was determined during storage at $-18^{\circ} \mathrm{C}$ for a period of 3 months to explore the possibilities of better utilization of this species by development of value added mince based products and to evaluate the shelf life during frozen storage. Mince from mrigal was used for preparation of value added products viz., fish cutlets and fish fingers. Microbiological counts were enumerated including total plate count, Staphylococcus aureus, Coliforms, psychotropic and other pathogenic bacteria. The TPC value of fish cutlet and finger decreased from $7.26 \times 10^{4}, 7.54 \times 10^{4}$ to $8.96 \times 10^{2}, 1.67 \times 10^{3} \mathrm{cfu} / \mathrm{gram}$ of sample respectively during storage. There was a significant increase in $\mathrm{pH}$ and TVBN value in fish finger and cutlet. Sensory acceptability decreased with increase in storage time. From the results it was observed that the estimated shelf life of fish cutlets and fish fingers was 150 and 145 days respectively.

\section{Introduction}

Man's quests for newer taste in foods know no bounds. This has lead to the development of a wide variety of coated food products, which have now become a part of culinary tradition. These foods include meat, poultry, vegetable, fruit and fish products that are covered with batter and breading before cooking. The first commercially developed coated product was 'fish finger' (Surendren et $a l ., 2003)$ later several other fish and fishery products became popular particularly with the advent of fast food trade. Battered and breaded products offer a convenience food valued widely by the consumer. There was an increase in consumers for fish and fishery products around the world in recent years due to recognition of their nutritive value. There is a wide scope for increasing the consumption by developing value added products (Rathod and Pagarkar, 2013). There are suggestions to 
use carps for the production of surimi and other value added products (Sankar and Ramachandran, 2005). Fish patties and fingers made from carps have been suggested as convenience products, as they are preferred to traditional preparations of this fish (Sehgal and Sehgal, 2002). Efforts have also been made to improve the quality and stability of ready to eat foods (Cakli et al., 2005).

Freezing and frozen storage of fish cutlet and fish fingers are commonly used because of the consistency, reliable quality, ease of transportation and the fact that they are very close to fresh equivalents (Tokur et al., 2004 and Sharma et al., 2000). Battered and breaded or coated systems have the benefits of versatility and familiarity because they enhance the flavor and texture of processed food products (Biswas et al., 2004).

Coating of meat products with edible materials provides better protection against oxidation and microbiological deterioration. It can also significantly enhance the sensory qualities of meat products and could be an effective method of value addition with better consumer acceptability (Ahamed et al., 2007). Considering the demand for ready to eat fish products especially in developing countries like India, there is an instant need to diversify our fish based products. Preparation of fish cutlet and fish finger is one such technology for diversification.

The important parameters which affect the shelf life of the stored products are the production form, features of packing material, storage temperature, packing process and machines that are used (Baygar et al., 2008). Based on this background, the aim of present study was set to develop ready to eat fish products from mrigal (Cirrhinus mrigala) and to determine the rate and the type of deterioration process that occurs during frozen storage.

\section{Materials and Methods}

Fresh mrigal with an average length and weight of $38.67 \pm 3.04 \mathrm{~cm}$ and $927.60 \pm 128.64$ $\mathrm{g}$ respectively was collected from the fishfarm, Muthukur, Nellore were used for the study. Fish was brought in iced condition and was processed manually into dressed fish, which was later converted to mince using a deboner (Safe World, Malaysia). The deboned fish meat was minced using mincer (Sirman, Italy) to obtain uniform size meat particles. The fresh minced meat obtained from mrigal was used for the preparation of fish cutlets and fish fingers. The recipes for the products were selected by comparing the acceptability of different formulations of ingredients by sensory evaluation.

\section{Preparation of fish cutlets}

Ingredients used for the preparation of fish cutlets from mrigal meat are presented in Table 1. Minced fish meat obtained from mrigal fish was cooked under $0.5 \mathrm{~kg} / \mathrm{cm}^{2}$ steam pressure for 20 minutes and cook drip was drained out. Boiled and peeled potatoes were mashed and mixed thoroughly with all other ingredients. Approximately $25 \mathrm{~g}$ of above material was taken, shaped into ball and flattened into round shape of $1 \mathrm{~cm}$ thickness. Battering was done by dipping in egg white and then rolled in the bread crumbs powder until uniform coating of breading material was formed on the surface. The cutlets thus prepared were frozen at $-40 \mathrm{C}$ for 2 hours and packed in HDPE pouches, sealed and stored at $-18^{\circ} \mathrm{C}$ for its quality evaluation.

\section{Preparation of fish fingers}

Ingredients used for the preparation of fish fingers from mrigal meat are presented in Table 2. The minced meat is mixed with all other ingredients to form the pasty mass of hard consistency and made into slabs and 
frozen at $-40^{\circ} \mathrm{C}$ in a freezer unit for 2 hours. The frozen slab was cut into fingers of uniform size the battered and breaded again frozen at $-40^{\circ} \mathrm{C}$ for 2 hours and packed in HDPE pouches and stored at $-18^{\circ} \mathrm{C}$ for its quality evaluation.

\section{Experimental design}

From the frozen stored lot, three pouches each of fish cutlets and fish fingers were randomly chosen and samples from each pouch were analyzed in triplicate for microbiological, biochemical and sensory attributes as described in the following sections. Sampling was done with time interval of every 15 days.

\section{Proximate, biochemical and microbial analysis}

Moisture, fat, protein and ash content were determined according to AOAC (2000). Differences in weight were recorded after drying the sample in hot air oven at $100 \pm 5^{\circ} \mathrm{C}$ overnight to determine the moisture content. Crude protein ( $\mathrm{TN} \times$ 6.25) and fat contents were determined by the micro-kjeldahl and soxhlet method respectively. Crude ash was determined by heating an incinerated sample in a muffle furnace at $550^{\circ} \mathrm{C}$ for 6 hours. Total volatile base nitrogen (TVBN) was determined by the micro diffusion method of Conway (1962). Thiobarbituric acid value (TBA) was determined by the method of Tarladgis et al., (1960), Peroxide value (PV) and Free fatty acid (FFA) were determined according to Jacobs (1958) and Olley and Lovern (1960) respectively. Microbiological examinations were carried out as per APHA (1992) methods.

\section{Sensory analysis}

Sensory characteristics of the fish cutlet, fish finger from mrigal minced meat were evaluated by selected panel members of the college who have experience in evaluation of similar products, on a nine-point scale and scores were assigned with ' 1 ' being the least and ' 9 ' being the highest for attributes as described by Reddy (1992). The characteristics evaluated during sensory evaluation were appearance, colour, odour, flavor, taste, texture and over all acceptability. The products were deep fried in refined sun flower oil until they were cooked before being presented to the panelists.

\section{Statistical analysis}

All analyses were carried out in triplicates and subjected to tests. Analysis of variance was performed by one-way ANOVA procedures with the application of Duncan's multiple range tests and descriptive statistics using SPSS 19 (SPSS, 2010). The least significant difference (LSD) was used to test for difference between means and significance was defined at $\mathrm{P}<0.05$. Results are reported as mean values of determinations \pm Standard Deviation.

\section{Results and Discussion}

The yield of mince was $38.51 \pm 0.97 \%$ from whole mrigal. The raw minced meat yield of fresh water fishes like common carp and silver carp varies from 40-47\% (Arekere, 1993; Siddaiah et al., 2001). The initial moisture, protein, fat and ash content of mrigal mince were found to be $75.01 \pm 0.82 \%$, $18.65 \pm 0.03 \%, 3.16 \pm 0.14 \%$ and $1.53 \pm 0.02 \%$ respectively. The proximate composition of mrigal is comparable to other fresh water fishes (Arekere, 1993; Siddaiah et al., 2001; Sehgal et al., 2010; Elyasi et al., 2010).

\section{Proximate analysis}

The changes in proximate composition of fish cutlet and finger during frozen storage are given in Table 3 and 4 respectively. During frozen storage of fish cutlet and fish finger, the moisture content decreased, which may be 
due to the drip loss during thawing of the products. Pandey and Kulkarni (2007) also reported a decrease in the moisture content in grass carp cutlets and fish fingers during the frozen storage at $-18^{\circ} \mathrm{C}$ for 6 months. Similar results were reported by Reddy (1992) in ready to serve fish products. The results were in agreement with the findings of Hassaballa et al., (2009) in fish finger with pre frying, Cakli et al., (2005) in fish fingers produced from sardine and Vanitha (2011) in fish cutlet and fish finger produced from Catla during the frozen storage.

The protein content of both the fish products (fish cutlet and fish finger) shown an increasing trend during frozen storage. The higher protein content may be attributed due to the addition of ingredients.

Lakshminatha et al., (1992) observed a significant increase in the protein content of fish finger from perches during frozen storage for 22 weeks. Raju et al., (1999) observed a significant increase in the protein content from 18.72 to $20.62 \%$ during the frozen storage of fish sticks from pink perch for 12 weeks.

The crude fat content of fish cutlet and fish finger increased from 5.47 \pm 0.09 to $6.01 \pm 0.27 \%$ and $6.93 \pm 0.07$ to $7.51 \pm 0.15 \%$ respectively. The gradual increase in ash content of fish cutlet and fish finger may be due to the loss of soluble inorganic constituents during thawing. Lakshminatha et al., (1992) and Raju et al., (1999) observed similar results during the frozen storage of fish fingers made from croakers during the frozen storage at $-20^{\circ} \mathrm{C}$ for 22 weeks and fish sticks from pink perch for 12 weeks. Higher lipid content may be attributed to frying in oil. High lipid content can promote enzymatic and non-enzymatic degradations and limit the shelf life of fish during frozen storage.

\section{Biochemical analysis}

The biochemical changes of fish cutlet and fish finger during frozen storage are given in Table 5 and 6 respectively. The $\mathrm{pH}$ of fish cutlet and fish finger showed an increasing trend, which might be due to retardation of protein degradation during frozen temperature $\left(-18^{\circ} \mathrm{C}\right)$ and might also be due to reduced microbial growth (Sahoo and Anjaneyulu, 1997). A similar increase in the $\mathrm{pH}$ was observed by Tokur et al., (2006) in fish fingers prepared from unwashed and washed mince of Cyprinus carpio. Similar results were observed by Yanar and Fenercioglu (1999) in fish balls from carp and Izci et al., (2011) in fish finger from sand smelt. $\mathrm{pH}$ of grass carp cutlets and fish fingers showed a significant increase during the frozen storage at $-18^{\circ} \mathrm{C}$ for 6 months (Pandey and Kulkarni, 2007).

At the initial stage of storage period, the values of $\mathrm{PV}$ for fish cutlet and fish finger were $10.06 \pm 0.03$ and $9.13 \pm 0.04 \mathrm{meqO}_{2} / \mathrm{kg}$ of fat and increased to 16.33 \pm 0.04 and $15.20 \pm 0.03 \mathrm{meq} \mathrm{O}_{2} / \mathrm{kg}$ of fat respectively at the end of 90 days of storage period which may be due to mechanical mincing of fish meat which accelerates oxidation due to the incorporation of oxygen in the tissue or the disruption and intermixing of tissue components.

Similar increase in the PV content was observed by Tokur et al., (2004) during the frozen storage of fish burger from tilapia. An increase in PV in case of frozen fish cutlet during frozen storage for 12 weeks was reported by Ninan et al., (2010).

Al-Bulushi et al., (2005) found an increase in $\mathrm{PV}$ from 14 to $23.7 \mathrm{meq} \mathrm{O}_{2} / \mathrm{kg}$ of fat during storage of fish burgers. 
Table.1 Ingredients used for the preparation of fish cutlets from mrigal meat

\begin{tabular}{|l|c|}
\hline \multicolumn{1}{|c|}{ Ingredients } & Quantity (\%) \\
\hline Fish meat & 44.5 \\
\hline Shrimp meat (Penaeus indicus) & 15.0 \\
\hline Potatoes & 10.0 \\
\hline Wheat flour & 3.3 \\
\hline Salt & 1.5 \\
\hline Mono sodium Glutamate & 0.2 \\
\hline Onion & 5.0 \\
\hline Baking powder & 0.1 \\
\hline Chilly powder & 1.0 \\
\hline Ginger & 0.2 \\
\hline Garam masala & 2.0 \\
\hline Coriander leaves & 0.2 \\
\hline Battering and breading material & 8.0 \\
\hline Egg white & 9.0 \\
\hline Bread crumbs & \\
\hline
\end{tabular}

*Refined sun flower oil is used for frying

Table.2 Ingredients used for the preparation of fish fingers from mrigal meat

\begin{tabular}{|c|c|}
\hline \multirow[b]{2}{*}{ Ingredients } & \multirow[b]{2}{*}{ Quantity (\%) } \\
\hline & \\
\hline Fish meat & 92.5 \\
\hline Wheat flour & 2.0 \\
\hline Salt & 1.5 \\
\hline Sugar & 1.0 \\
\hline Chilly powder & 2.0 \\
\hline Cumin seed & 0.24 \\
\hline Onion & 0.26 \\
\hline Garlic & 0.24 \\
\hline Pepper & 0.24 \\
\hline Sodium tripolyphosphate & 0.02 \\
\hline \multicolumn{2}{|c|}{ Battering and breading material } \\
\hline Egg white & 8.0 \\
\hline Bread crumbs & 9.0 \\
\hline
\end{tabular}

*Refined sun flower oil is used for frying 
Table.3 Proximate composition of Fish cutlets during frozen storage

\begin{tabular}{|c|c|c|c|c|}
\hline $\begin{array}{c}\text { Storage period } \\
\text { (Days) }\end{array}$ & $\begin{array}{c}\text { Moisture* } \\
(\%)\end{array}$ & $\begin{array}{c}\text { Protein* }^{*} \\
(\%)\end{array}$ & $\begin{array}{c}\text { Fat* }^{*} \\
(\%)\end{array}$ & $\begin{array}{c}\text { Ash* } \\
(\%)\end{array}$ \\
\hline 0 & $58.37 \pm 0.15^{\mathrm{e}}$ & $16.05 \pm 0.08^{\mathrm{a}}$ & $5.47 \pm 0.09^{\mathrm{a}}$ & $3.11 \pm 0.08^{\mathrm{a}}$ \\
\hline 1 & $57.84 \pm 0.25^{\mathrm{e}}$ & $16.37 \pm 0.09^{\mathrm{b}}$ & $5.56 \pm 0.10^{\mathrm{b}}$ & $3.15 \pm 0.10^{\mathrm{ab}}$ \\
\hline 15 & $56.87 \pm 0.14^{\mathrm{d}}$ & $16.56 \pm 0.09^{\mathrm{c}}$ & $5.63 \pm 0.10^{\mathrm{c}}$ & $3.18 \pm 0.02^{\mathrm{bc}}$ \\
\hline 30 & $56.11 \pm 0.11^{\mathrm{c}}$ & $16.77 \pm 0.04^{\mathrm{d}}$ & $5.68 \pm 0.28^{\mathrm{d}}$ & $3.21 \pm 0.12^{\text {cd }}$ \\
\hline 45 & $55.31 \pm 0.19^{\mathrm{b}}$ & $16.97 \pm 0.15^{\mathrm{e}}$ & $5.75 \pm 0.08^{\mathrm{e}}$ & $3.23 \pm 0.08^{\text {cde }}$ \\
\hline 60 & $54.98 \pm 0.11^{\mathrm{b}}$ & $17.28 \pm 0.09^{\mathrm{f}}$ & $5.83 \pm 0.10^{\mathrm{f}}$ & $3.27 \pm 0.05^{\text {def }}$ \\
\hline 75 & $53.23 \pm 0.26^{\mathrm{a}}$ & $17.55 \pm 0.14^{\mathrm{g}}$ & $5.94 \pm 0.09^{\mathrm{g}}$ & $3.32 \pm 0.03^{\text {ef }}$ \\
\hline 90 & $52.93 \pm 0.83^{\mathrm{a}}$ & $17.86 \pm 0.03^{\mathrm{h}}$ & $6.01 \pm 0.27^{\mathrm{h}}$ & $3.36 \pm 0.01^{\mathrm{f}}$ \\
\hline
\end{tabular}

*Each value is represented as the mean \pm SD of $n=3$

${ }^{\text {abcdef }}$ Means followed by the same superscript with in a column are not significantly different $(P>0.01)$.

Table.4 Proximate composition of Fish fingers during frozen storage

\begin{tabular}{|c|c|c|c|c|}
\hline $\begin{array}{c}\text { Storage period } \\
\text { (Days) }\end{array}$ & $\begin{array}{c}\text { Moisture* } \\
(\%)\end{array}$ & $\begin{array}{c}\text { Protein }^{*} \\
(\%)\end{array}$ & $\begin{array}{c}\text { Fat* } \\
(\%)\end{array}$ & $\begin{array}{c}\text { Ash* } \\
(\%)\end{array}$ \\
\hline 0 & $64.41 \pm 0.09^{\mathrm{h}}$ & $15.15 \pm 0.18^{\mathrm{a}}$ & $6.93 \pm 0.07^{\mathrm{a}}$ & $2.52 \pm 0.09^{\mathrm{a}}$ \\
\hline 1 & $63.98 \pm 0.16^{\mathrm{g}}$ & $15.42 \pm 0.11^{\mathrm{b}}$ & $7.05 \pm 0.17^{\mathrm{b}}$ & $2.55 \pm 0.04^{\mathrm{b}}$ \\
\hline 15 & $63.12 \pm 0.06^{\mathrm{f}}$ & $15.72 \pm 0.09^{\mathrm{c}}$ & $7.19 \pm 0.29^{\mathrm{c}}$ & $2.58 \pm 0.08^{\mathrm{ab}}$ \\
\hline 30 & $62.72 \pm 0.09^{\mathrm{e}}$ & $16.07 \pm 0.17^{\mathrm{d}}$ & $7.22 \pm 0.10^{\mathrm{d}}$ & $2.60 \pm 0.06^{\mathrm{bc}}$ \\
\hline 45 & $61.89 \pm 0.10^{\mathrm{d}}$ & $16.36 \pm 0.09^{\mathrm{e}}$ & $7.28 \pm 0.09^{\mathrm{e}}$ & $2.62 \pm 0.03^{\mathrm{c}}$ \\
\hline 60 & $61.12 \pm 0.18^{\mathrm{c}}$ & $16.61 \pm 0.08^{\mathrm{f}}$ & $7.33 \pm 0.09^{\mathrm{f}}$ & $2.64 \pm 0.06^{\mathrm{cd}}$ \\
\hline 75 & $60.14 \pm 0.05^{\mathrm{b}}$ & $16.93 \pm 0.10^{\mathrm{g}}$ & $7.46 \pm 0.24^{\mathrm{g}}$ & $2.68 \pm 0.08^{\mathrm{de}}$ \\
\hline 90 & $59.75 \pm 0.10^{\mathrm{a}}$ & $17.26 \pm 0.09^{\mathrm{h}}$ & $7.51 \pm 0.15^{\mathrm{h}}$ & $2.71 \pm 0.08^{\mathrm{e}}$ \\
\hline
\end{tabular}

*Each value is represented as the mean \pm SD of $n=3$

abcdef Means followed by the same superscript with in a column are not significantly different $(\mathrm{P}>0.01)$.

Table.5 Biochemical Analysis of Fish cutlets during frozen storage

\begin{tabular}{|c|c|c|c|c|c|}
\hline $\begin{array}{l}\text { Storage } \\
\text { period } \\
\text { (Days) }\end{array}$ & $\mathrm{pH}^{*}$ & $\begin{array}{c}\mathrm{PV}^{*} \\
\left(\mathrm{meqO}_{2} / \mathrm{kg} \text { of }\right. \\
\text { fat) }\end{array}$ & $\begin{array}{c}\text { FFA* } \\
\text { (\% of Oleic } \\
\text { acid) }\end{array}$ & $\begin{array}{c}\mathrm{TBA}^{*} \\
\text { (mg MA } / \mathrm{kg} \\
\text { of sample) }\end{array}$ & $\begin{array}{c}\text { TVBN }^{*} \\
\text { (mg/100g of } \\
\text { meat) }\end{array}$ \\
\hline 0 & $6.37 \pm 0.02^{\mathrm{a}}$ & $10.06 \pm 0.03^{\mathrm{a}}$ & $0.0027 \pm 0.00^{\mathrm{a}}$ & $0.35 \pm 0.01^{\mathrm{a}}$ & $1.07 \pm 0.03^{\mathrm{a}}$ \\
\hline 1 & $6.42 \pm 0.02^{b}$ & $11.72 \pm 0.02^{b}$ & $0.0034 \pm 0.00 \mathrm{~b}$ & $0.47 \pm 0.04^{b}$ & $1.25 \pm 0.04^{\mathrm{a}}$ \\
\hline 15 & $6.49 \pm 0.01^{\mathrm{c}}$ & $12.38 \pm 0.01^{\mathrm{c}}$ & $0.0048 \pm 0.00^{c}$ & $0.54 \pm 0.06^{\mathrm{c}}$ & $1.59 \pm 0.02^{\mathrm{b}}$ \\
\hline 30 & $6.54 \pm 0.01^{\mathrm{d}}$ & $12.96 \pm 0.01^{\mathrm{d}}$ & $0.0051 \pm 0.00^{c}$ & $0.68 \pm 0.03^{\mathrm{d}}$ & $1.94 \pm 0.03^{\mathrm{c}}$ \\
\hline 45 & $6.58 \pm 0.03^{\mathrm{d}}$ & $13.43 \pm 0.04^{\mathrm{e}}$ & $0.0059 \pm 0.00^{c}$ & $0.76 \pm 0.01^{\mathrm{e}}$ & $2.21 \pm 0.02^{\mathrm{d}}$ \\
\hline 60 & $6.63 \pm 0.02^{\mathrm{e}}$ & $14.76 \pm 0.01^{\mathrm{t}}$ & $0.0063 \pm 0.00^{\mathrm{e}}$ & $0.83 \pm 0.02^{\mathrm{f}}$ & $2.66 \pm 0.03^{\mathrm{e}}$ \\
\hline 75 & $6.65 \pm 0.01^{\mathrm{ef}}$ & $15.59 \pm 0.02^{\mathrm{g}}$ & $0.0071 \pm 0.00^{f}$ & $0.92 \pm 0.01^{\mathrm{g}}$ & $2.98 \pm 0.14^{\mathrm{f}}$ \\
\hline 90 & $6.69 \pm 0.03^{\mathrm{f}}$ & $16.33 \pm 0.04^{\mathrm{h}}$ & $0.0076 \pm 0.00^{\mathrm{g}}$ & $1.01 \pm 0.03^{\mathrm{h}}$ & $3.27 \pm 0.28^{\mathrm{g}}$ \\
\hline
\end{tabular}

*Each value is represented as the mean \pm SD of $n=3$

${ }^{\text {abcdef }}$ Means followed by the same superscript with in a column are not significantly different $(\mathrm{P}>0.01)$. 
Table.6 Biochemical analysis of fish fingers during frozen storage

\begin{tabular}{|c|l|l|c|c|c|}
\hline $\begin{array}{c}\text { Storage } \\
\text { period } \\
\text { (Days) }\end{array}$ & $\mathrm{pH}^{*}$ & $\begin{array}{c}\mathrm{PV}^{*} \\
\left(\mathrm{meqO}_{2} / \mathrm{kg}\right. \\
\text { fat) }\end{array}$ & $\begin{array}{c}\text { FFA }^{*} \\
(\% \text { of Oleic } \\
\text { acid) }\end{array}$ & $\begin{array}{c}\text { TBA }^{*} \\
(\mathrm{mg} \mathrm{MA} / \mathrm{kg} \\
\text { of sample) }\end{array}$ & $\begin{array}{c}\mathrm{TVBN}^{*} \\
(\mathrm{mg} / 100 \mathrm{~g} \text { of } \\
\text { meat) }\end{array}$ \\
\hline 0 & $6.30 \pm 0.02^{\mathrm{a}}$ & $9.13 \pm 0.04^{\mathrm{a}}$ & $0.0017 \pm 0.00^{\mathrm{a}}$ & $0.31 \pm 0.02^{\mathrm{a}}$ & $1.09 \pm 0.01^{\mathrm{a}}$ \\
\hline 1 & $6.38 \pm 0.03^{\mathrm{b}}$ & $10.68 \pm 0.01^{\mathrm{b}}$ & $0.0023 \pm 0.00^{\mathrm{a}}$ & $0.37 \pm 0.04^{\mathrm{b}}$ & $1.12 \pm 0.03^{\mathrm{ab}}$ \\
\hline 15 & $6.44 \pm 0.05^{\mathrm{c}}$ & $11.58 \pm 0.01^{\mathrm{c}}$ & $0.0033 \pm 0.00^{\mathrm{b}}$ & $0.46 \pm 0.02^{\mathrm{c}}$ & $1.18 \pm 0.02^{\mathrm{ab}}$ \\
\hline 30 & $6.51 \pm 0.01^{\mathrm{d}}$ & $12.04 \pm 0.01^{\mathrm{d}}$ & $0.0044 \pm 0.00^{\mathrm{c}}$ & $0.52 \pm 0.04^{\mathrm{d}}$ & $1.26 \pm 0.04^{\mathrm{cc}}$ \\
\hline 45 & $6.58 \pm 0.03^{\mathrm{e}}$ & $12.76 \pm 0.02^{\mathrm{e}}$ & $0.0051 \pm 0.00^{\mathrm{d}}$ & $0.60 \pm 0.02^{\mathrm{e}}$ & $1.39 \pm 0.06^{\mathrm{cd}}$ \\
\hline 60 & $6.63 \pm 0.02^{\mathrm{e}}$ & $13.29 \pm 0.02^{\mathrm{f}}$ & $0.0064 \pm 0.00^{\mathrm{e}}$ & $0.73 \pm 0.04^{\mathrm{f}}$ & $1.52 \pm 0.05^{\mathrm{d}}$ \\
\hline 75 & $6.72 \pm 0.04^{\mathrm{f}}$ & $14.84 \pm 0.05^{\mathrm{g}}$ & $0.0076 \pm 0.00^{\mathrm{f}}$ & $0.85 \pm 0.03^{\mathrm{g}}$ & $1.81 \pm 0.17^{\mathrm{e}}$ \\
\hline 90 & $6.79 \pm 0.02^{\mathrm{g}}$ & $15.20 \pm 0.03^{\mathrm{h}}$ & $0.0083 \pm 0.00^{\mathrm{g}}$ & $0.94 \pm 0.04^{\mathrm{h}}$ & $2.96 \pm 0.11^{\mathrm{f}}$ \\
\hline
\end{tabular}

*Each value is represented as the mean $\pm \mathrm{SD}$ of $\mathrm{n}=3$

${ }^{\text {abcdef }}$ Means followed by the same superscript with in a column are not significantly different $(P>0.01)$.

Table.7 Microbial analysis of fish cutlets and fish fingers during frozen storage

\begin{tabular}{|c|c|c|c|c|}
\hline \multirow[b]{2}{*}{$\begin{array}{l}\text { Storage } \\
\text { period } \\
\text { (Days) }\end{array}$} & \multicolumn{2}{|c|}{ Fish cutlets } & \multicolumn{2}{|c|}{ Fish fingers } \\
\hline & $\begin{array}{c}\text { TPC* }^{*} \\
\text { (cfu/gram of } \\
\text { meat) }\end{array}$ & $\begin{array}{l}\text { Psychrophiles* } \\
\text { (cfu/gram of } \\
\text { meat) }\end{array}$ & $\begin{array}{c}\text { TPC* } \\
\text { (cfu/gram of } \\
\text { meat) }\end{array}$ & $\begin{array}{c}\text { Psychrophiles* } \\
\text { (cfu/gram of } \\
\text { meat) }\end{array}$ \\
\hline 0 & $7.26 \times 10^{4}(4.86)$ & $9.63 \times 10^{3}(3.98)$ & $7.54 \times 10^{4}(4.87)$ & $2.48 \times 10^{4}(4.39)$ \\
\hline 1 & $6.27 \times 10^{4}(4.79)$ & $8.52 \times 10^{3}(3.93)$ & $3.16 \times 10^{4}(4.49)$ & $1.75 \times 10^{4}(4.24)$ \\
\hline 15 & $3.96 \times 10^{4}(4.59)$ & $7.34 \times 10^{3}(3.86)$ & $2.35 \times 10^{4}(4.37)$ & $6.81 \times 10^{3}(3.83)$ \\
\hline 30 & $5.35 \times 10^{3}(3.72)$ & $5.23 \times 10^{3}(3.71)$ & $1.58 \times 10^{4}(4.19)$ & $5.96 \times 10^{3}(3.77)$ \\
\hline 45 & $4.27 \times 10^{3}(3.63)$ & $2.51 \times 10$ & $6.45 \times 10^{3}(3.80)$ & $4.34 \times 10^{3}(3.63)$ \\
\hline 60 & $3.74 \times 10^{3}(3.57)$ & $1.23 \times 1$ & $3.72 \times 10^{3}(3.57)$ & $3(3.40)$ \\
\hline 75 & $2.88 \times 10^{3}(3.45)$ & $8.71 \times 10^{2}(2.94)$ & $2.53 \times 10^{3}(3.40)$ & $3.87 \times 10^{2}(2.58)$ \\
\hline 90 & $8.96 \times 10^{2}(2.95)$ & $7.82 \times 10^{2}(2.89)$ & $1.67 \times 10^{3}(3.22)$ & $2.65 \times 10^{2}(2.42)$ \\
\hline
\end{tabular}

*Each value is represented as the mean of two estimates

Figure in the parenthesis indicates Log. psychrophilic bacterial count $\mathrm{cfu}=$ colony forming units

Table.8 Sensory analysis of fish cutlets and fish fingers during frozen storage

\begin{tabular}{|c|c|c|}
\hline Storage period (Days) & Fish cutlets & Fish fingers \\
\hline 0 & $8.94 \pm 0.09^{\mathrm{e}}$ & $8.81 \pm 0.09^{\mathrm{f}}$ \\
\hline 1 & $8.62 \pm 0.07^{\mathrm{e}}$ & $8.60 \pm 0.11^{\mathrm{f}}$ \\
\hline 15 & $8.13 \pm 0.19^{\mathrm{d}}$ & $8.19 \pm 0.04^{\mathrm{e}}$ \\
\hline 30 & $7.80 \pm 0.03^{\mathrm{c}}$ & $8.02 \pm 0.14^{\mathrm{e}}$ \\
\hline 45 & $7.61 \pm 0.41^{\mathrm{c}}$ & $7.72 \pm 0.12^{\mathrm{d}}$ \\
\hline 60 & $7.04 \pm 0.07^{\mathrm{b}}$ & $7.10 \pm 0.27^{\mathrm{c}}$ \\
\hline 75 & $6.96 \pm 0.11^{\mathrm{b}}$ & $6.78 \pm 0.15^{\mathrm{b}}$ \\
\hline 90 & $6.59 \pm 0.07^{\mathrm{a}}$ & $6.45 \pm 0.20^{\mathrm{a}}$ \\
\hline
\end{tabular}

*Each value is represented as the mean \pm SD of $n=7$.

${ }^{\text {abcdef }}$ Means followed by the same superscript with in a column are not significantly different $(\mathrm{P}>0.01)$. 
Fig.1 Regression equation of storage period on over all acceptability scores of mrigal fish cutlets during frozen storage

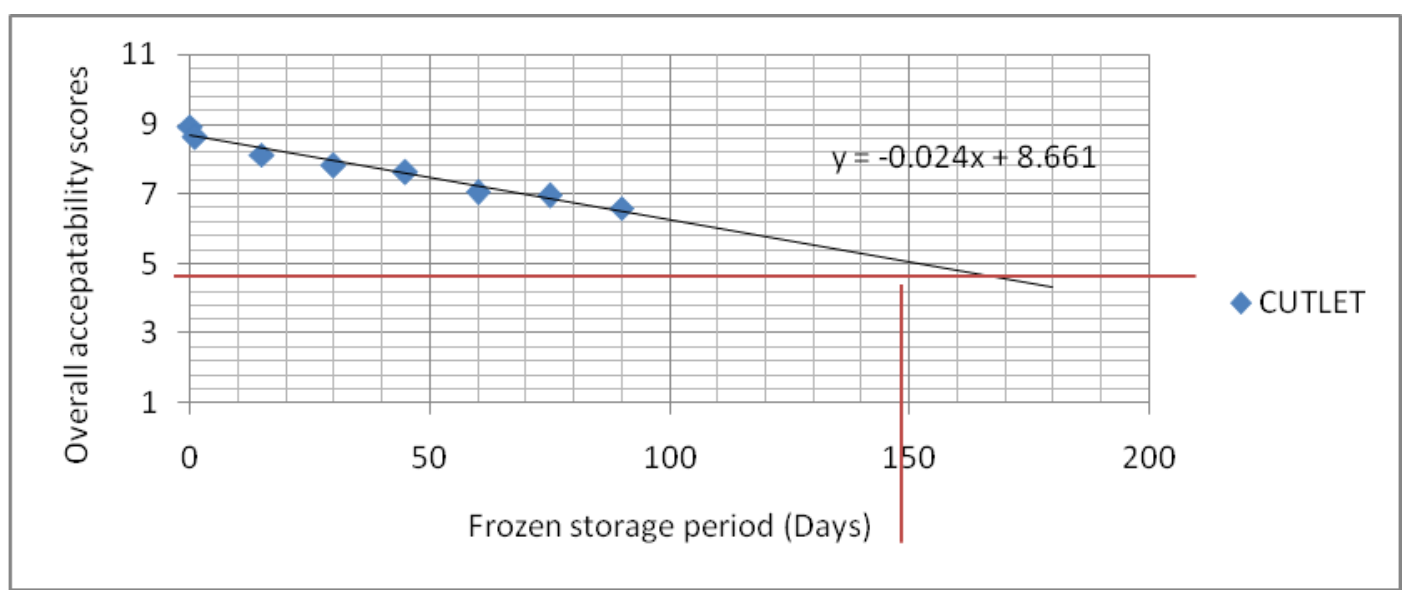

Fig.2 Regression equation of storage period on over all acceptability scores of mrigal fish Fingers during frozen storage

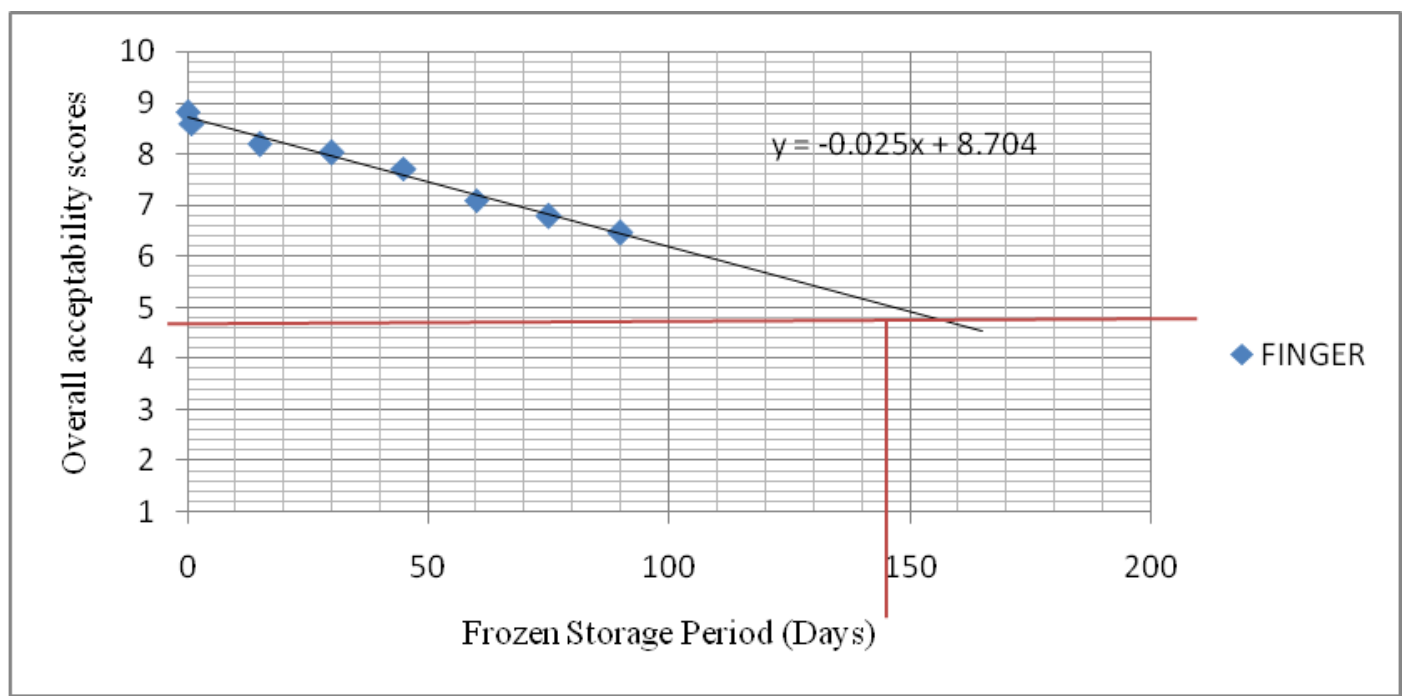

The changes in FFA content of fish cutlet and fish finger are presented in Table 5 and Table 6 respectively. There was a significant increase in the FFA content of fish cutlet and fish finger during storage.

A significant increase in the FFA was observed by Tokur et al., (2004) during the frozen storage of fish burger upto 8 months. Ninan et al., (2010) found that FFA concentration increased in fish cutlet prepared from tilapia minced meat stored at $-20 \mathrm{C}$. It was also found that the FFA concentration of mackerel (Scombers combrus) mince in frozen storage $\left(-10^{\circ} \mathrm{C}\right)$ increased with the duration of storage and the degree of mincing of the meat (Brake and Fennema, 1999). Oxidative hydrolysis of lipids in the meat during storage could cause deterioration in the quality of the meat resulting in the formation of FFA (Huss, 1971). Pandey and Kulkarni (2007) found that the FFA concentration in grass carp fish cutlet and fish finger increased during the frozen storage for 6 months. 
The changes in TBA during the frozen storage of fish cutlet and fish finger are presented in Table 5 and Table 6 respectively. A steady increase in the TBA value was observed in fish cutlet and fish finger during frozen storage. The increase in TBA could be because of the retardation of lipid oxidation by products of lipid hydrolysis and interaction of malonaldehyde with proteins. A significant increase in the TBA value during frozen storage has been observed by Ninan et al., (2010) in fish cutlet stored at $-20^{\circ} \mathrm{C}$ for 21 weeks.

The TVBN content in fish cutlet and fish fingers reached to $3.27 \pm 0.28$ and $2.96 \pm 0.11$ $\mathrm{mg} / 100 \mathrm{~g}$ of meat from the initial value of $1.07 \pm 0.03$ and $1.09 \pm 0.01 \mathrm{mg} / 100 \mathrm{~g}$ of meat respectively after 90 days of storage period. Ninan et al., (2010) observed a significant increase in TVBN during the frozen storage of fish cutlet prepared from tilapia meat. Pandey and Kulkarni (2007) observed a significant increase in the TVBN value of grass carp fish cutlet and fish finger during the frozen storage for 6 months. Progressive hydrolysis and putrification process under the influence of microbial enzymes leads to production of volatile bases and these volatile bases shown an exponential increase leading to deterioration of odour and flavor. Similar results were obtained by Mahmoudzadeh et al., (2010) in fish burger prepared from deep flounder and brush tooth lizard fish. The increasing of TVBN value during storage is related to bacterial spoilage and activity of endogenous enzymes (Chomnawang et al., 2007).

\section{Microbial analysis}

The results of TPC and Psychrophilesare presented in the Table 7 . Initial reduction in the microbial load could be due to the freezing and the powerful antimicrobial properties of food additives. A decrease in the
TPC of fish cutlet and fish finger was observed during the frozen storage for a period of 90 days. Liston (1980) observed that freezing generally causes a reduction in bacterial count and the number will continue to fall during storage. A similar decrease in the TPC count was found by the Al-bulushi et al., (2005) and Ninan et al., (2010) during the frozen storage of fish burger from Arabian sea meagre at $-20^{\circ} \mathrm{C}$ for 3 months and frozen storage of value added products from Tilapia, respectively. Lethal effects of temperature just below the freezing point are more deleterious than the very low storage temperature for the survival of bacteria (Arafa and Chen, 1976). Pathogenic bacteria were not detected in any of the products during the entire period of frozen storage. The products were found to be free from Salmonella, Vibrio spp. and Faecal streptococci, yeast and moulds. Similar results have been reported by the many researchers during the frozen storage of different products (Mahmoudzadeh et al., 2010; Al-bulushi et al., 2005; Ninan et al., 2010; Raju et al., 1999 and Ahamed et al., 2007).

\section{Sensory analysis}

The overall acceptability scores of fish cutlet and fish finger during frozen storage are presented in Table 8 and Figure 1 and 2. The overall acceptability of the fish cutlet and fish finger (judged for appearance, colour, flavour and taste) were within the acceptable limit at the end of 90 days of storage period. Freshly prepared products received an initial score above 8 and were rated as good. On correlating the sensory scores with the storage period of fish cutlet and fish finger during the frozen storage, it was observed that the shelf life of fish cutlet and fish finger were to be 150 and 145 days respectively. Pandey and Kulkarni (2007) reported the shelf life of five months for fish cutlets and four months for the fish fingers prepared from grass carp 
during the frozen storage for 6 months. Joseph et al., (1984) has reported the shelf life of 19 weeks for raw cutlets in frozen conditions prepared from the cooked mince of different marine fishes. Raju et al., (1999) reported a shelf life of 12 weeks for fish sticks prepared from pink perch stored at $-20^{\circ} \mathrm{C}$.

The shelf life of crab cutlets and crab sticks were 24 weeks during frozen storage (Raju et al., 2000). Cakli et al., (2005) has reported the shelf life of 8 months for fish fingers in frozen storage prepared from mince of different fish species. Additions of various ingredients that have antioxidant properties such as polyphosphate (Huffman et al., 1987), egg white (Yetim and Ockerman, 1995) and dry spices and ginger (Abd-El-Alim et al., 1999) might have protected the products from development of rancidity during the storage period.

With the increase in the population, there is a change in the people's attitude to consume foods that are ready to eat and have nutritional value. From the results, it was observed that fish cutlet and fish finger were in acceptable condition till the end of storage till 90 days.

By correlating the sensory scores with the storage period, the estimated shelf life of fish cutlet and fish finger during frozen storage was found to be 150 and 145 days respectively. This study provides information on the development shelf life of fish cutlet and fish fingers during frozen storage to fishery products manufacturers and retailers.

\section{References}

Abd-El-Alim, S.S., Lugasi, A., Horari, J and Dworchak, E. 1999. Culinary herbs inhibit lipid oxidation in raw and cooked minced meat patties during storage. J. Sci. Food Agri., 79: 277-285.

Ahamed, M.E., Anjaneyulu A.S.R., Sathu, T.,
Thomas, R and Kondaiah, N. 2007.Effect of enrobing on the quality and shelf life of buffalo meat cutlets under frozen storage. J. Muscle Food, 18: 19-34.

Al-bulushi, I.S., Stefan, K., Hamed, A and Sultan, A. 2005. Evaluating the quality and storage stability of fish burger during frozen storage. Fish. Sci., 71: 648-654.

AOAC. 2000. Official Methods of Analysis of Association of Analytical Chemists International, $17^{\text {th }}$ Edition, Suite 500, 481 North Frederick Avenue, Gaithersburg, Maryland 20877-2417 USA.

APHA. 1992. Compendium of Methods for the Microbiological Examination of Foods, (Ed.) M. L. Speck, APHA Publication, Washington, USA.

Arafa, A.S and Chen, T.C. 1976. Quality characteristics of convenience chicken products as related to packaging and storage. J. Food Sci., 41: 18-22.

Arekere, G. 1993. Effect of freezing and frozen storage on the properties of proteins from common carp (Cyprinus carpio) M.F.Sc thesis. University of Agricultural Sciences, Bangalore, India.

Baygar, T., Erkan, N., Mol, S., Ozden, O., Ucok, D and Yildirim, Y. 2008. Determination of the shelf-life of trout (Oncorhynchus mykiss) raw meatball that packed under modified atmosphere. Pak., J.Nutri.,7(3):412-417.

Biswas, A.K., Keshri, R.C and Bisht, G.S. 2004.Effect of enrobing and antioxidants on quality characteristics of precooked pork patties under chilled and frozen storage conditions. Meat Sci., 66(3):733741.

Brake, N.C., and Fennema, O.R. 1999. Lipolysis and lipid oxidation in frozen minced mackerel as related to rate of molecular diffusion and presence of gelatin. J. Food Sci., 64: 25-32.

Cakli, S. K., Taskaya, L., Kisla, D., Celik, U., Ataman, C. A., Cadun, A., Kilinic, B andMaleki, R. H. 2005. Production and quality of fish fingers from different fish species. Eur. Food Res. Technol., 220: 526-530. 
Chomnawang, C., Nantachai, K., Yongsawatdigul, J., Thawornchinsombut, S and Tungkawachara, S. 2007. Chemical and biochemical changes of hybrid catfish fillet stored at $4^{\circ} \mathrm{C}$ and its gel properties. Food Chem., 103: 420-427.

Conway, E. J. 1962. Microdiffusion Analysis of Volumetric Error, $5^{\text {th }}$ edn. Crospy Lockwood and Son Ltd., London.

Elyasi, A., Zakipour Rahim Abadi, E., Sahari, M.A and Zare, P. 2010. Chemical and microbial changes of fish fingers made from mince and surimi of common carp (Cyprinus carpio L., 1758). Int. Food Res. J., 17: 915-920.

Hassaballa, A.Z., Mohamed, G.F., Ibrahim, H.M and Abdelmageed, M. A. 2009. Frozen cooked catfish burger: Effect of different cooking methods and storage on its quality. Global Vet., 3(3): 216-226.

Huffman, D.L., Ande, C.F., Cordray, J.C., Stanley, M.H and Egbert, E.R. 1987. Influence of polyphosphate on storage stability of restructured beef and pork nuggets. J. Food Sci., 52(2): 275-278.

Huss, H.H. 1971. In: R. Kreuzer (Ed), Fish inspection and quality control. Fishing News (Books) Ltd. Farnham, U.K. pp: 60.

Izci, L., Bilgin, $S$ and Gunlu, A. 2011.Production of fish finger from sand smelt (Atherina boyeri, RISSO 1810) and determination of quality changes. Afr. J. Biotechnol., 10(21): 4464-4469.

Jacobs, M.B. 1958. The chemical analysis of Foods and food products. Krieger Publication Co., New York, UK.393-394.

Joseph, J., Perigreen, P.A and Thampuran, N. 1984. Preparation and storage of cutlet from low priced fish. J. Fish Technol., 21: 70-74.

Lakshminatha, R., Setty, T.M.R and Dora, K.C. 1992. Studies on the storage behavior of fish fingers from croakers and perches. J. Fish. Technol., 29: 35-39.

Liston, J. 1980. Microbiology in fisheries sciences. In: Advances in Fish Science and Technology, (J.J. Connel, ed.) pp. 138-157, FNI (Books), Farnham, Survey, UK.
Mahmoudzadeh, M., Motallebi, A.A., Hosseini, H., Haratian, P., Ahmadi, H., Mohammadi, M and Khaksar, R. 2010. Quality assessment of fish burgers from deep flounder (Pseudorhombus elevates) and brushtooth lizardfish (Sauridaundo squamis) during storage at $-18^{\circ} \mathrm{C}$. Iran. J. Fish. Sci., 9(1): 111-126.

Ninan, G., Bindu, J and Joseph, J. 2010. Frozen storage studies of value added mince based products from tilapia (Oreochromis mossambicus, Peters 1852). J. Food Process. Preserv., 34: 255-271.

Olley, J. and Lovern, J.A. 1960. Phospholipids hydrolysis of cod flesh stored at various temperatures. J. Sci. Food Agric., 11:644652.

Pandey, B.N and Kulkarni, G.K. 2007. A study on the deep frozen fish cutlets and fingers prepared from different carp species. Fish. Fish Toxicol., Pp. 75-90.

Raju, C.V., Dhananjaya, S and Reddy, G.V.S. 1999. Preparation and cold storage studies on ready-to-fry sticks from pink perch (Nemipterus japonicus). J.Aquat. Biol., 14: 111-114.

Raju, C.V., Dhananjaya, S and Reddy, G.V.S. 2000.Studies on the freezing and frozen storage of ready to fry crab products.J. Aquat. Biol., 15: 115-118.

Rathod, N and Pagarkar, A. 2013. Biochemical and sensory Quality changes of fish cutlets made from pangasius fish (Pangasianodon hypophthalamus), during storage in refrigerated display unit at -15 to $-18^{\circ}$ C. Int. J. Food Agri. Vet. Sci., 3(1): $1-8$.

Reddy, G.V.S. 1992. Development of ready to serve fish products using lactic fermentation, 44. Ph.D. Thesis, University of Agricultural Science, Bangalore.

Sahoo, J and Anjaneyulu, A.S.R 1997. Effect of natural antioxidants and vacuum packaging on the quality of buffalo meat nuggets during refrigerated storage. Meat Sci., 47: 223-230.

Sankar, T.V and Ramachandran, A. 2005. Thermal stability of myofibrillar protein 
from Indian major carps. J. Sci. Food Agr., 85: 563-568.

Sehgal, H.S and Sehgal, G. K.2002.Aquacultural and socio-economic aspects of processing carps into some value-added products. Bioresour. Technol., 82: 291-293.

Sehgal, H.S., Sehgal, G.K., Thind, S.S., Kaur, A and Rehal, J. 2010.Development of "fish mince pakora" from a cultured carp species, Labeorohita (Ham).J. Food Process. Preserv., 34: 15-23

Sharma, J., Reddy, G.V.S and Srikar, L.N. 2000. Effect of frozen storage on lipids and functional properties of proteins of dressed Indian oil sardine (Sardinalla longiceps). Food Res. Int., 33: 815-820.

Siddaiah, D., Reddy, G.V.S., Raju, C.V and Chandrasekhar, T.C. 2001. Changes in lipids, proteins and kamaboko forming ability of silver carp (Hypophthalmich thysmolitrix) mince during frozen storage. Food Res. Int., 34: 47-53.

SPSS., 2010, SPSS for windows. Release 19. Chicago, 11: SPSS Inc.

Surendran, P.K, Mathew, P.T., Nirmala, T., Narayana nambiar, V., JoseJoseph, Boopendranath, M.R., Lakshmanan.P.T and Viswanathan Nair 2003. Seafood safety. Society of Fisheries Technologists (India), Cochin. 1-12.
Tarladgis, B.G., Watts, $\mathrm{M}$ and Younathan, $\mathrm{M}$. 1960. A distillation method for the quantitative determination of malonaldehyde in rancid foods. J. Oil Chem. Soc., 37: 44-48.

Tokur, B., Ozkutuk, S., Atici, E., Ozyurt, G and Ozyurt, C.E. 2006. Chemical and sensory quality changes of fish fingers, made from mirror carp (Cyprinus carpio), during frozen storage $\left(-18^{\circ} \mathrm{C}\right)$. Food Chem.,99:335-341.

Tokur, B., Polat, A., Beklevik, G and Ozkutuk, S. 2004. The quality changes of tilapia (Oreochromis niloticus) burger during frozen storage. Eur. Food Res. Technol., 218(5): 20-423.

Vanitha.M., 2011. Development of value added products from Catla (Catlacatla) and its quality evaluation. M.F.Sc, Thesis, Sri Venkateswara Veterinary University, Tirupati.

Yanar, Y and Fenercioglu, H. 1999. The utilization of carp (Cyprinus carpio) flesh as fish ball. Turk. J. Vet. Anim. Sci., 23: 361-365.

Yetim, H. and Ockerman, H.W. 1995. The effects of egg white, tumbling and storage time on proximate composition and protein fractions or restructured fish products. J. Aquat. Food Prod. Technol., 4(1):65-77.

\section{How to cite this article:}

Sandhya Rani, T., K. Dhanapal, G.V.S. Reddy, D.R.K. Reddy, K. Sravani and Praveen Kumar, G. 2017. Quality Assessment of Mince Based Products Made from Mrigal (Cirrhinus mrigala) During Frozen Storage. Int.J.Curr.Microbiol.App.Sci. 6(12): 3230-3241. doi: https://doi.org/10.20546/ijcmas.2017.612.376 